\title{
Special Edition on Chinweizu
}

\section{Chinweizu: Over Forty Years of Reflections on Africa, Asia and the World}

\author{
Lloyd G. Adu Amoah \\ Director, Centre for Asian Studies, University of Ghana, Legon, Ghana \\ lgamoah@ug.edu.gh \\ Lawrence Ogbo Ugwuanyi \\ Professor of Philosophy and Director of Internship and Linkages Services \\ Unit (ILS), University of Abuja, Abuja, Nigeria \\ lawrence.ugwuanyi@uniabuja.edu.ng
}

\section{General Introduction}

In what has become a classic Chinweizu in his The West and the Rest of Us: White Predators, Black Slavers and the African Elite (1975) offered penetrating comparative insights on the postcolonial condition of Africa and Asia. He will remain on the same trajectory in his chapter, "Africa and the Capitalist Countries" (1993) in the UNESCO General History of Africa, VIII: Africa Since 1935, edited by Ali Mazrui. Chinweizu's large body of work has been shot through by such Africa-Asia and other pertinent reflections and this special edition of African and Asian Studies, Volume 20 (Number 1-2), attempts to engage these. It should be emphasized at the very onset that this special edition is not about Chinweizu's autobiography or biography even if tangentially linked (in terms of especially his body of work). It is the outcome of a twoday conference convened by the Nigeria based Centre for Critical Thinking and Resourceful Research in Africa (CECTRRA) with the active support of the Centre for Asian Studies (CAS, University of Ghana), and held on November 5-6, 2018 at the Institute of African Studies, University of Ghana, Legon.

The conference was the first of what CECTRRA has dubbed Outstanding African Thinkers (OAT) Conference, and is a project which aims at locating distinguished minds of African extraction who have sustained the African intellectual tradition and privileged the intellectual resources of Africans in advancing scholarship and intellectualism. The vision of the conference is that there should emerge a new form of intellectual tradition for intellectual workers of Africa through a deliberate effort to discuss the ideas of those who 
could justifiably be called intellectual elders in the African thinking field. Why was Chinweizu singled out for attention in this inaugural conference project? There are a number of reasons and they deserve to be highlighted.

Almost in a manner reminiscent of that ancient and rare perfect commitment to the pursuit of knowledge and truth by such ageless intellectuals like the Ethiopian Zera Yacob, the Greek Socrates and the Chinese Confucius, the Nigerian intellectual Chinweizu demonstrates before our very eyes that a life of total commitment to knowledge and scholarship devoid of other entanglements is possible in Africa. This total devotion to knowledge and thinking has paid off handsomely and, after more than 40 years after his emergence on the intellectual scene at the world level with his famous book, The West and the Rest of Us: White Predators, Black Slavers and the African Elite (1975), Chinweizu has consistently churned out many outstanding, thought-provoking works that unreservedly require detailed engagement and analysis.

Admittedly wide-ranging, the scholarship of Chinweizu is richly multidisciplinary. Consequently, the conference took on the multi-disciplinary posture and provided a forum for a number of scholars to articulate, critique, problematize as well as justify the claims of Chinweizu on, and/or about, Africa in a manner that revealed the weight and worth of his writings. The conference attracted scholars from a wide range of disciplines and areas studies - African Studies, Africana Studies, Asian Studies, Kemetology, Philosophy, History, Literary Studies, Political Science, Gender Studies, and Cultural Studies, etc. who engaged the works of Chinweizu.

The publications in this edition represent a careful selection of the presentations made at this important conference that fall broadly into three parts. These parts should not be understood as distinct and separate but rather entangled and therefore capturing the complex thematic inter-relays that mark Chinweizu's own work.

The first part is made up of articles which discuss the wisdom of Chinweizu on how, through a committed engagement and deep rooted understanding of the challenges of modern Africa anchored on its own millennia of wisdom, lessons could be drawn from Asia's modern developmental experiences. As cultural and economic collaborations deepen between Africa and Asia, these articles utilize the views drawn from Chinweizu, one of Africa's foremost modern polymaths, on how the continent can be positioned from a self-conscious knowledge base to enable it profit from its ongoing Asian interactions.

The second set of the articles confront Western hegemonic designs on Africa and outline what can be done to address this challenge as can be read through the works of Chinweizu. The third set of articles are those that discuss the ideas of Chinweizu on women through cogitations on his well-known book, Anatomy of female power: A Masculinist Dissection of Matriarchy (1990). 
Amoah and Quame hold the fort with two articles on Chinweizu's cogitations on Africa-Asia relations. Chinweizu (2015) has argued that East Asia's example (in particular China, Japan and India) of industrialization and modernization premised on an intelligent adoption and adaptation of Western ideas and practices in combination with the culture of these countries should be a compelling one for Africa. This in his view can be achieved by taking seriously Asian Studies in contemporary Africa's educational system - a path that in his understanding will heal the "Niggerization"1 of the African. Amoah and Quame wrestle with the call to action imperative inherent in Chinweizu's advise by examining the counter-hegemonic processes (as an exemplar for Black Africa) by which the Centre for Asian Studies (CAS) was established and is being run at the University of Ghana, Legon.

Chinweizu's (2004) invocation of strategies must be understood as intimately connected to his dire warning (2010) that the emergence of a Black African Super Power (just as the Asians have theirs in China) in the next 100 years is the surest guarantee for the survival of the Black race. The recent murder by the police of George Floyd, an African American man in Minnesota, United States, on May 27, 2020, triggered worldwide protests against global systemic and institutional racism directed at Blacks, a tragedy which makes paying attention to Chinweizu's warning critical. The question to ask though is whether he is not engaging in wishful thinking (Amzat, 2020). Amoah attempts to rescue Chinweizu's admonishment from the wishful thinking charge through a critical dialectical dialogue with the Chinweizuan literature (on the emergence of a Black African Super Power this century).

In his Reith Lecture in 1979, Ali Mazrui argues that "Africa's weakness is mainly due to three things: technological underdevelopment, organisational incompetence and military impotence." Leshoele takes up the last of this Mazruian triad and re-examines it four decades later through Chinweizuan categories using the defense spending of two of Africa's largest economies, Nigeria and South Africa, as case studies. Leshoele's central insight is that "without serious political will and dedication to building Africa's nuclear weapons capability, diplomatic engagements with the rest of the world as equal partners will remain a pipe dream and the looting of Africa's mineral wealth will continue unabated." To be sure, Black Africa's military feebleness has been tied to its weak scientific and technological capabilities (which Mazrui notes in the preceding quote) which it has been argued emanates from the absence of any history of note in these areas.

1 By this term Chinweizu means the psychic damage that was inflicted on Black Africans by the Maafa, the African Holocust (1441-1945). 
Chinweizu debunks the intellectual warfare inherent in the myth of Black Africa's lack of scientific and technological history by carefully assembling evidence covering 432 centuries going back into Africa's antiquity and spanning virtually all corners of the African continent. Chinweizu presents "13 exhibits of spectacular African achievements in science. They range in time from ca. 43200 BC to $195^{2} \mathrm{AD}$. And they range geographically from Lesotho in Southern Africa; to Kenya, Uganda and Tanzania in East Africa; to the Democratic Republic of the Congo in Central Africa; to Egypt in North Africa; and to Nigeria in West Africa."

Ugwuanyi's article reflects on Chinweizu's On Ubontology (2004), an important monograph which provocatively re-centres knowledge as the core for the struggle for black liberation. Ugwuanyi's work provides a critique of the positions in the monograph by focusing on its strengths and weaknesses with the view to locating the future relevance of the ideas. The work also considers other options that can lead to mental liberation in Africa that are not be captured by the monograph.

The eminent Ghanaian writer and thinker, Ayi Kwei Armah, who is now based in Senegal, has dedicated his lucubrations in recent times to Black African antiquity and has thereby been excavating and clarifying Kemetic ideas and concepts. A recent effort is the magisterial work, Wat nt Shemsw: The Way of Companions (2018), which provides his take on Maat, the moral principle (Asante, 200o, p.xi) superintending Ancient Egyptian life.

Kambon in his article reviews and critiques this work in the spirit of Chinweizu's (2018) own rebuttal at the conference. Kambon's central agenda is to test Armah's claims on Maat against Kemetic texts and archaeological data as part of further scientific validation and clarification of this ancient African principle.

God'spresence and Ezeifeka dig into Chinweizu's (1990) forensic analysis of female power as being dominant over that of the male in Africa through the agency of biological and social contrivances he identifies. The duo think that Chinweizu inspires a gender clash or worse deepens the gender wars by a clever gesture in support of patriarchy; they suggest a cease fire that is post gender, humanist in scope and contemporary African woman empowering (in their particular lights).

The articles in this Special Edition celebrate Chinweizu's work by way of rigorous cerebration which he himself endorses in his constant reference to Amilcar Cabral's (Cabral \&Davidson, 1979) maxim of constant open critique of others and self.

The Journal of African and Asian Studies, in our view, is an appropriate forum for discussing Chinweizu's thought and extending this charge for constant, 
open, and genuine critique. This journal has long been consistent - and one of the unique ones doing so - in focusing on the interface between African and Asian scholarship on the pressing issues facing two of the world's most ancient civilizations and cultures. Chinweizu's work has also been concerned about such interconnections making the journal the best natural fit for this special issue. Ultimately every scholar working on African and Asian affairs should find this special issue on one of the most consistent and compelling thinkers on the subject matter useful. Our hope is that by reflecting on the work of notable Black African thinkers such as Chinweizu the ground has been laid for more of such endeavours going forward in the field of African and Asian studies.

\section{References}

Amzat, Jimoh. 2020. "Beyond Wishful Thinking: The Promise of Science Engagement of the Community Level in Africa." Journal of Developing Societies 36(2):206-228.

Armah, Ayi Kwei. 2018. Wat nt Shemsw: The Way of Companions. Popenguine: Per Ankh. Asante, Molefe. 200o. The Egyptian Philosophers: Ancient African Voices from Imhotep to Akhenaton. Illinois: African American Images.

Cabral, Amilcar and Davidson, Basil. 1979. Unity and Struggle: Speeches and Writings of Amilcar Cabral. New York, NY: Monthly Review Press.

Chinweizu. 1990. Anatomy of Female Power: A Masculinist Dissection of Matriarchy. Lagos: Pero Press.

Chinweizu. 1993. "Africa and the Capitalist Countries." In UNESCO General History of Africa, VIII: Africa Since 1935, edited by Ali Mazrui, 769-797. Paris and Oxford: UNESCO and Heinnemann.

Chinweizu. 2004. On Ubuntology: Groundwork for the Intellectual Autonomy of the Black World. A Monograph.

Chinweizu. 2010. "Pan-Africanism and a Black Super Power-The 21st century Agenda." Paper Presented at the CBAAC conference on Pan-Africanism, Abuja. Nigeria.

Chinweizu. 2015. "On Niggerology: Groundwork for the Study and Exorcising of the Nigger Demon from the Black World," Paper Presented at the First Asian Studies in Africa Conference, University of Ghana, Legon.

Chinweizu 2018. "Armah's Sankofa effort': an evaluation/critique of Armah's 'Maat and Cooperative egalitarian social organization," A Paper Presented at The First Outstanding African Thinkers Conference on Chinweizu, University of Ghana, Legon.

Mazrui, Ali. 1979. "The African Condition.” Reith Lectures. British Broadcasting Corporation. 